Marquette University

e-Publications@Marquette

$1-1-2014$

\title{
Interest Groups, Think Tanks, and Health Care Policy (1960s-Present)
}

Susan Giaimo

Marquette University, susan.giaimo@marquette.edu

Published version. "Interest Groups, Think Tanks, and Health Care Policy (1960s-Present)," in Guide to U.S. Health and Health Care Policy. Ed. Thomas R. Oliver. Thousand Oaks CA: SAGE Publications/CQPress, 2014: 375-392. Permalink. (C) 2014 SAGE Publications/CQPress. Used with permission. 


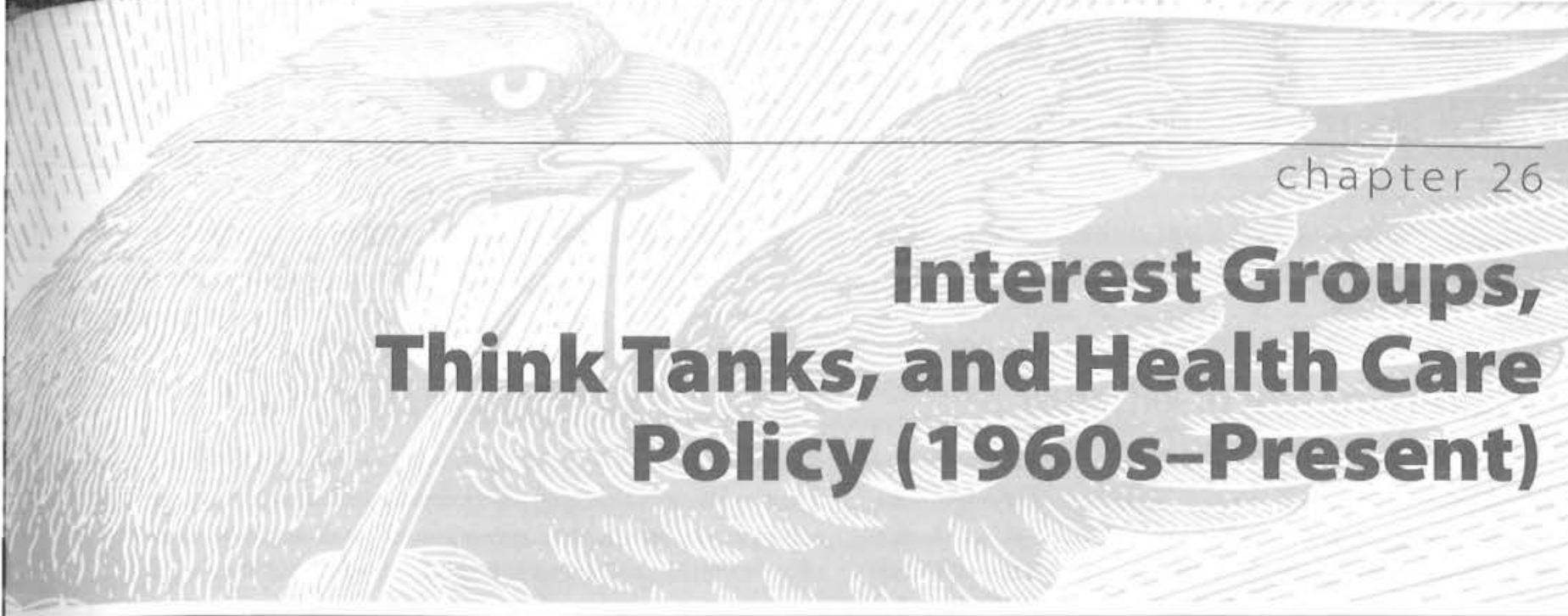

Susan Giaimo

N U.S. POLITICS, INTEREST GROUPS AND RESEARCH institutes have served as important sources of policy proposals for members of Congress and the executive branch. The nation's porous political system's institutional fragmentation contains numerous "veto points" at which organized interests can modify and even block legislation they dislike. Interest groups can enter the fray during the multiple points of the legislative process. They can lobby the executive branch at federal and state levels to modify the rules governing the implementation of a law. They can challenge a law in the courts.

Time and again, interest groups have blocked the enactment of health policies. Repeated failed efforts by politicians to expand health care coverage to the American people in the twentieth century is a case in point, as associations representing health care providers, insurers, employers, and even senior citizens succeeded in blocking or repealing such laws. However formidable organized interests are in the policy process, they are neither impregnable nor static. On the contrary, their policy preferences and policy influence can and do change as conditions in the economy and in the health care sector change. Coalitions in favor of or opposed to the expansion of health insurance, and national health insurance in particular, have changed in both their composition and strength. Although interest groups successfully opposed Democratic and Republican presidents' efforts to introduce universal government health insurance, in some cases they have supported the creation of public insurance programs for particular segments of the population or the expansion of private insurance under the shadow of government sponsorship.

The health care arena has become a dynamic and increasingly crowded policy field with a bewildering array of stakeholders seeking to influence policymakers. Until the 1960 s, the number of interest groups in health policy was small and concentrated, and their positions were fairly constant and predictable. Since then, new interest groups have entered the arena, many of them focused on fairly narrow concerns of their members. This teeming environment reflects broader changes in the interest group landscape, with the explosion in the number of interest groups associated with social movements of the 1960 s and 1970s. It also highlights the mobilization of new health care stakeholders in reaction to the growing role of the federal and state governments in health care financing and provision following the enactment of Medicare and Medicaid in 1965.

The overarching lines of conflict in U.S. health policy have been over the balance between public and private, or government and market, forces in health care financing and provision. These battle lines were drawn in the early twentieth century with the first ill-fated attempt to introduce national health insurance and have continued ever since. Interest groups have been key players in public battles over such fundamental questions. Yet they also have worked behind the scenes to shape the details of health care legislation and its implementation to serve the interests of their members.

In exploring interest group activity in U.S. health policy since the 1960 s, we concentrate here on three major efforts to expand health insurance coverage during this time period: the passage of Medicare and Medicaid, the failure to enact the Clinton Health Security plan, and the enactment of the Patient Protection and Affordable Care Act (PPACA). We do not, however, attempt to portray interest group activity on the range of health policy issues 
that do not involve high-level officials and partisan maneuvering or to describe interest group influence on state health policies.

\section{EARLY OPPOSITION TO NATIONAL HEALTH CARE INSURANCE}

The major forces opposed to a larger government role in national health insurance were a constellation of health care providers led by the American Medical Association (AMA) and its allies in business and the insurance industry who joined forces with members of Congress to block social policy initiatives of (mostly) Democratic presidents. From the 1930s until 1964, an anti-reform coalition composed of the AMA, private insurers, and employers was able to thwart national health insurance initiatives by teaming up with a conservative coalition of southern Democrats and northern Republicans in Congress. The passage of Medicare and Medicaid in 1965 under President Lyndon B. Johnson (1963-1969) was a rare defeat for this anti-reform coalition and reflected a new partisan reality in Congress following the watershed election of 1964 . Yet both programs, by deliberate design, fell far short of universal coverage and targeted subgroups of the U.S. population. While extending health insurance to seniors, the poor, and the disabled, Medicare and Medicaid made concessions to the medical profession and private insurers in order to win their participation and support. ${ }^{1}$

The next major attempt at national health insurance occurred in 1993-1994 under President William J. Clinton (1993-2001). His effort to wed market competition with government regulation and compulsory national insurance was met by fierce and successful resistance among key stakeholders in the insurance industry and business community whose oppositional stance found common ground in a disciplined Republican Party and Democratic defectors in Congress. The executive branch's strategy of excluding health care stakeholders from meaningful negotiations on the terms of health care reform alienated opponents and contributed to the defeat of the initiative. ${ }^{2}$

President Barack Obama (2009- ), however, succeeded where President Clinton had failed. Unlike Clinton, Obama at the outset pursued a strategy of inclusion with major health care stakeholders, making concessions to former foes of reform and thereby neutralizing health care providers and insurers and employers who had blocked previous reform efforts. Determined Democrats in Congress held together and withstood unified Republican opposition to enact a law that greatly expanded health insurance coverage while still falling short of universal national health insurance. In following this strategy of inclusion, Obama accepted limits to the scope of reform: the PPACA preserved the premier role of private insurance and introduced only cautious provisions to alter the health care delivery system and the payment of providers.

\section{RESEARCH INSTITUTES AND INTEREST GROUPS IN AMERICAN HEALTH POLICY}

Research institutes (commonly known as think tanks) often serve as the wellspring of policy ideas, with interest groups acting as the vessels that carry such ideas along the stream of policymaking. The separation, however, is not always so neat; often, interest groups play a greater role than simply transmitting policy ideas. Indeed, groups seek to mold such ideas into legislative proposals that stand a chance of passage by Congress and approval by the president. To succeed in this endeavor, they must often forge alliances with each other and with partisan forces in Congress and the executive branch. Often, they will undertake public campaigns to influence public opinion in order to win policy battles.

Research institutes offer policy ideas that interest groups or political parties take up and translate into legislative initiatives. Research institutes also undertake policy analysis of legislative proposals or existing programs, and their reports can influence the process and content of legislative proposals. Some think tanks are independent entities; others promote policies that toe a clear ideological line and are closely identified with particular interest groups or political parties. Research institutes are patient players in the policy fray: unlike elected politicians, who must face the timetable of frequent elections, research institutes can wait; the policy ideas they promote often suffer several legislative defeats over the course of decades before becoming law.

Many major research institutes in the health policy arena are active in the political arena. Those that seek to analyze policy and disseminate information in a more dispassionate manner and using accepted social scientific research methods are the Kaiser Family Foundation and the Commonwealth Fund. Others produce respected analyses using scholarly and social scientific research methods, but have an identifiable leaning either for or against government intervention in health care. Among the former are the Brookings Institution, the Urban Institute, and the Robert Wood Johnson Foundation, while the American Enterprise Institute is among the latter. Increasingly, research institutes that adopt a clear ideological or partisan line have become active players in health policy debates. For example, the Cato Institute and the Heritage Foundation have advocated free market ideas and disparaged what they see as "big government" in health care. The chief think tank promoting an active government role in health care is the Public Policy Research Institute.

The relationships between research institutes and policymakers may be close. For example, the Heritage Foundation has been a champion of "premium support" as 
a way to reform Medicare and control the costs of the program. Premium support is a fixed-premium contribution from the federal government that seniors would use to purchase coverage from competing private insurers or from the traditional government Medicare plan. It is a controversial proposal, not least because it would transform Medicare from a defined benefit to defined contribution plan and would require seniors who chose a plan that was more expensive than the government's premium support to shoulder the additional cost. Although not the originator of premium support, the Heritage Foundation has promoted the idea in its publications and also has written favorably on Representative Paul Ryan's (R-WI; in office 1999- ) versions of it in his budget proposals. The foundation also provided economic analysis of Ryan's budget proposals at his request. ${ }^{3}$

\section{Interest Groups}

Interest groups represent in the policy process those who share a common concern. They do not run candidates for political office themselves, but they may support particular candidates and parties. Interest groups transmit the demands of civil society to government policymakers. The theory of pluralism holds that interest groups compete with one another in an effort to influence policymakers, and the government is a neutral arbiter or referee among them. The policies enacted reflect the free play of ideas. In reality, however, some groups are more powerful than others. They may be better organized and have more money with which to fund their political activities than their rivals. Groups that represent the business interests tend to be more powerful in terms of money spent on political campaigns and lobbying than those representing labor unions, the environment, or consumers.

Interest groups seek to influence policymakers through a number of ways. Chief among them is money to finance election campaigns. Political action committees (PACs) are the entities created by interest groups to channel campaign contributions to candidates whom they believe will be sympathetic to their policy concerns. While larger interest groups had created their own PACs in the 1940s, these organizations became more prominent in the 1970s. In the wake of the Watergate scandal, Congress enacted reforms in the 1970 s designed to weaken the say of party leaders in selecting candidates at national party conventions and to set out rules for channeling campaign contributions to PACs. Perversely, these laws displaced party bosses only to make interest groups the chief players in candidate selection and election campaign finance. By 2009, 4,618 PACs were registered with the Federal Election Commission (FEC), the government agency that oversees them. ${ }^{4}$

\section{Money and Interest Groups}

Beginning with the presidential election of 2000 , the influence of money in politics became more pronounced through the rise of soft money and issue advocacy groups, known by their Internal Revenue Service designations, 527s and $501(c)(4)$ s. Unlike PACs, which must abide by FEC rules limiting the amount of contributions and specifying strict reporting requirements, $527 \mathrm{~s}$ and $501(\mathrm{c})(4) \mathrm{s}$ are largely unregulated and have become an avenue for interest groups to give unlimited amounts of money to election campaigns and issue advocacy efforts. Donors to such financing vehicles do not face any limits to their contribution amounts. Furthermore, the Supreme Court's ruling in Citizens United v. Federal Election Commission (2010) declared corporations to be persons possessing the right of free speech under the First Amendment, essentially freeing them from prior campaign and issue advocacy contribution restrictions. ${ }^{5}$

Interest groups also influence policymaking through lobbying members of Congress and the executive branch. Lobbyists meet with policymakers and seek to persuade them to adopt their group's position on a bill. Lobbyists provide key information to policymakers and may even help craft legislation or administrative rules. Groups may also mobilize their grassroots members to contact members of Congress or the president at critical moments in the legislative process. Finally, interest groups will also mount public campaigns and political advertising to try to shape public opinion and the position of policymakers. Lobbying activities are less subject to government regulation than campaign financing. Groups must report their lobbying expenditures to the federal government but, unlike contributions to PACs and election campaigns, face no limits on such spending. ${ }^{6}$

\section{Hyperpluralism}

The interest group landscape has become much more crowded since the late 1960 s, so hyperpluralism is an apt description. Starting in the 1960 s, the cozy world of a relatively small number of interest groups representing the economic interests of business and labor in closed-door meetings with congressional committee leaders and the cabinet was transformed by an explosion of new groups promoting particular causes, such as civil rights, feminism, peace, and environmentalism. In 2011, there were 12,220 registered lobbyists in the nation's capital.?

Not only do policymakers confront a far greater number of interest groups, but these associations are also narrower in scope than their economic predecessors. ${ }^{8}$ Such hyperpluralism makes it difficult for interest groups and their contacts in Congress or the executive branch to forge durable alliances on policy initiatives, particularly those proposing sweeping health care reforms. Indeed, several different associations represent the business community and are often at odds with each other on health policy reform. Interest group power in this environment is better described as negative power: groups are too numerous and fragmented to take positive action, but they can block a policy 
initiative." Their ability to veto a policy initiative is made easier by the porousness of the U.S. political system, in which separation of powers and federalism offer numerous points of entry to organized interests. Numerous points in the legislative process give groups access to block a policy initiative, from the subcommittee and committee stages to floor votes in the House of Representatives and the Senate, to watering down a law by lobbying executive agencies or state governments at the rule-making and implementation stages, and finally, mounting lawsuits through the courts.

The growth in the number of interest groups since the 1960 s not only reflects the activities of social movements and citizen groups but also is the product of government health policies. President Johnson's domestic policy initiatives of the Great Society aimed to eliminate poverty in the nation. The Great Society, which constituted the biggest expansion of the federal government in social policy since the New Deal of the 1930s, created two important government health insurance programs, Medicare for senior citizens and Medicaid for the poor and disabled. These programs, like others associated with the Great Society, created new stakeholders and interest groups with a direct interest in the implementation of these programs.

\section{Interest Groups and Their Allies}

Interest group power also depends on alliances forged among different organized stakeholders (that is, with other groups) as well as the partisan allies in Congress and the executive branch. Democrats and Republicans are more sympathetic to some groups than others. While the rules are not hard and fast, Democrats are more inclined to listen to groups promoting organized labor, women, minorities, and patient advocates, while Republicans tend to identify with business interests more generally and with providers and insurers in the health care arena.

However, the power and influence of interest groups change over time. Seemingly impregnable alliances may unravel and new coalitions may take their place. Such alterations in interest group politics may occur for a number of reasons. New groups may enter the health policy arena to challenge existing coalitions. Coalitions may change in response to new challenges in the broader economy or within the health care system itself. In the face of such an altered environment, groups may redefine their interests, their policy preferences, and their partnerships. Changes in the partisan composition in Congress and the executive branch and in the ideological outlook in the Democratic and Republican parties themselves may provide organized interests and policymakers with opportunities to forge novel alliances around policy initiatives. All of these factors must be kept in mind when seeking to understand the form of a policy initiative and its fate in the policymaking process.

\section{Major Interest Groups in Health Policy}

The health policy universe has greatly expanded since President Johnson's enactment of Medicare and Medicaid in 1965. The major groups are those representing health care providers, insurers, employers, unions, and patients. In the battle over Medicare, the major interests were the AMA, representing doctors; the American Hospital Association (AHA); the American Federation of Labor and the Congress of Industrial Organizations (AFL-CIO), the peak association representing trade unions; and a handful of groups representing the business community and insurers. ${ }^{10}$ The AMA spent $\$ 1.2$ million (or $\$ 10$ million in 2010 dollars) in 1965. ${ }^{11}$ In 1993, when President Clinton attempted national health insurance, health care stakeholders numbered more than eleven hundred interest groups. ${ }^{12}$ The power of the AMA and AFL-CIO was greatly diminished, and they were two voices among many, including employers, consumers, insurers, and providers. Employers were represented by a number of competing associations, including the Business Roundtable, the Chamber of Commerce, and the National Federation of Independent Business. Likewise, the insurance industry was represented by two different groups: the American Association of Health Plans (AAHP), representing large managed care plans, and the Health Insurance Association of America (HIAA), whose members included smaller insurers.

In 2009, when President Obama embarked on his health care reform effort, he encountered many of the same interest groups as well as those representing the pharmaceutical industry (Pharmaceutical Research and Manufacturers of America) and medical device manufactures, and new citizens' groups and political movements that coordinated the efforts of interest groups into broad pro- and antireform coalitions. Among the latter were Organizing for America and MoveOn in support of health care reform and the Tea Party groups in opposition to it. Groups on both sides of the divide spent $\$ 3.3$ billion in lobbying in 2009. ${ }^{13}$ The health care reform effort also led to the founding of new groups, such as the National Association of State Health Cooperatives.

\section{THE PASSAGE OF MEDICARE AND MEDICAID IN 1965}

In 1960, the health care system in the United States was largely a private affair. Voluntary employer-provided private insurance covered the majority of working-age Americans and their dependents. This state of affairs was the product of previous failures to enact universal national health insurance. ${ }^{14}$ Yet for those outside the labor force, insurance was hard to come by. Private insurers shunned the aged, poor, and disabled as unprofitable risks. Because these groups were outside the labor market, they were not covered by the system 
of voluntary occupationally based insurance. It was precisely these categories of the "deserving" and "truly needy" who were deemed eligible for government intervention.

A diverse reform coalition brought together actors with different but reconcilable interests. Health care reformers in the Democratic Party viewed the provision of health insurance to senior citizens as a policy that could muster public support and expand their voting base among the elderly, while also appeasing interest groups that had opposed national health insurance initiatives in the past, such as commercial insurers and employers. The proposal also found favor with traditional Democratic allies such as organized labor, which wanted to shift responsibility for retiree health insurance from collective bargaining agreements to the government. President Johnson pursued a strategy of co-optation to neutralize potential opponents in the health care community.

The initial reform proposal was a contributory social insurance program modeled on Social Security pensions and financed from payroll taxes. Medicare would be a universal compulsory social insurance program for all seniors once they reached sixty-five years of age. As with Social Security, all seniors would be automatically enrolled in the program. The insurance would be a single-payer government program covering hospital care, which was far and away the most expensive portion of medical care at that time. The proposal carried a high degree of legitimacy and public support; after all, no one expected senior citizens to remain in the workforce. It was also difficult to justify medical bankruptcy or forgoing necessary health care due to old age.

The interest group universe in the battle over Medicare and Medicaid was sparsely populated by contemporary standards. The groups in favor of Medicare were peak associations representing organized labor, retirees, and those health care providers who provided care for seniors, such as the AFL-CIO, the American Association of Retired Workers, the American Geriatrics Society, and the National Coalition of Senior Citizens (itself a creation of the AFL-CIO). Except for the AFL-CIO, most of these groups lacked political muscle. This pro-reform coalition faced a much more powerful alliance of health care providers, insurers, and employers. These consisted of the American Medical Association, the American Hospital Association, the National Association of Blue Shield Plans (the health insurance for doctors' services run by state branches of the AMA), the Life Insurance Association of America, the National Association of Manufacturers, the Chamber of Commerce, the American Farm Bureau Federation (the mainstream group representing farmers in the political arena), and the American Legion..$^{15}$

\section{Interest Groups Gain Concessions}

Given the forces arrayed against Medicare and Medicaid, how did these programs ever get enacted into law? The answer lies in a combination of factors. The new partisan political terrain in Washington following the 1964 election set the stage for enactment of the Great Society programs, the biggest expansion of the welfare state since the New Deal of the 1930s. In addition, President Johnson and congressional leaders forged a bipartisan agreement on a compromise proposal that created the new social insurance programs of Medicare and Medicaid but fell far short of national health insurance, which served to mute potential opposition to reform. ${ }^{16}$

The first factor was the emergence of a new interest group alliance supporting government health insurance for senior citizens and the poor. The new coalition drove a wedge between stakeholders that had long opposed national health insurance while bringing together groups that were normally at odds with each other: the AFL-CIO representing organized labor and the HIAA representing commercial insurers, and the nonprofit, provider-run Blue Cross-Blue Shield plans. The AFL-CIO supported social insurance for seniors because it would relieve it of the task of negotiating retiree health benefits, which ate into the benefits of current workers. Removing retirees from collective bargaining would allow unions to focus their efforts on winning higher wages and fringe benefits for current workers. Insurance companies were predisposed to government insurance for seniors because this demographic tended to have higher medical costs and was therefore not profitable to insure. Besides, most seniors could not afford to purchase individual health plans because of the practice of experience rating, whereby insurers set premiums to a person's medical condition. A government program for all seniors would allow commercial and nonprofit insurers to focus on working-age adults and their families who were profitable. Like they did with the elderly, commercial insurers also shunned the poor and disabled because of their unprofitability. Moreover, these groups were long considered the responsibility of state and local government welfare programs.

\section{Concessions Concerning Medicare and Medicaid}

The AMA, however, vociferously opposed Medicare and Medicaid and resorted to the same argument of "socialized medicine" that it had used so effectively to defeat national health insurance efforts in earlier decades. Yet this time, it could not count on the insurance industry as an ally. Thus isolated, the AMA lacked the muscle to halt the enactment of Medicare and Medicaid.

Even so, doctors, along with hospitals and insurers, won significant concessions in the final bill that secured their place in the new programs. Policymakers did so in a preemptive fashion; they wanted to be sure that doctors and hospitals would participate in the new public insurance programs, so they sweetened them to buy off the support of powerful health care stakeholders. Hence, providers in 
Medicare and Medicaid would receive fee-for-service reimbursement. Of course, this form or reimbursement is inherently inflationary, because it encourages volume and expensive high-tech procedures, allowing providers to bill for each item of service and rewarding high-tech procedures. Hospitals won an additional concession of "cost plus 2 percent," which allowed them to bill an additional 2 percent on their fee-for-service itemizations. Not only did the AMA preserve fee-for-service, but doctors also evaded anything approaching nationally set prices. Instead, they would be reimbursed the "usual, customary, and reasonable" rates prevailing in their locality. Insurers also did quite well under Medicare and Medicaid. Responsibility for claims processing and provider reimbursement of these public insurance programs fell not to a government agency but instead to commercial and nonprofit insurers such as Blue Cross and Blue Shield.

The new political environment was the second factor that set the stage for the enactment of Medicare and Medicaid. The assassination of President John F. Kennedy (1961-1963) in November 1963 was a traumatic event for the country and directly and forcefully contributed to the outcome of the momentous 1964 presidential and congressional elections. Along with the election of Lyndon B. Johnson as president, Democrats swept both houses of Congress, securing majorities of sixty-eight seats in the Senate and 295 seats in the House of Representatives. The biggest change was the entry of liberal-minded Democrats from the urban north and the concomitant fading of the power of conservative southern Democrats in Congress who had stymied social reform by Democratic presidents since the 1930s and 1940s. President Johnson secured an electoral mandate and the congressional votes to enact his antipoverty programs.

This new political terrain fed directly into the bipartisan deal on Medicare and Medicaid. The Democratic chairman of the House Ways and Means Committee, Wilbur Mills (D-AR; in office 1939-1977), created a bill that combined three different reform approaches to forge an agreement between Democrats and Republicans in Congress. The "three-layer cake" proposal drew together an AFL-CIO proposal for hospital insurance, an AMA proposal for optional insurance to cover physician services, and the existing Kerr-Mills program enacted in 1960, which provided limited federal grants to states to care for their impoverished elderly. This three-layer cake became Medicare Part A, mandatory insurance for seniors to cover hospital and limited skilled nursing care expenses; Medicare Part B, optional insurance to cover physician services; and Medicaid, the joint federal-state insurance program covering the disabled and defined categories of the poor. ${ }^{17}$

Medicare and Medicaid represented a complex compromise that deliberately addressed the concerns of an array of stakeholders. President Johnson enhanced the chances of passage of these programs by pursuing a strategy of inclusion and co-optation of powerful potential opponents. Thus, Medicare Part A addressed concerns of the AFL-CIO and other groups representing the elderly who wanted hospital insurance for seniors. Part B's concessions to the AMA and private insurers muted their opposition. Medicaid brought needed federal assistance to state and local governments for the case of the poor and disabled. The bipartisan nature of the deal allowed both parties to claim credit for legislation that had broad public support.

Medicare and Medicaid constituted a mixed legacy in the history of social policy in the United States. The creation of new government insurance programs for the most vulnerable groups of the population was the biggest single expansion of the welfare state since the New Deal. Yet Medicare and Medicaid did not represent the stepping stone to imminent national health insurance as supporters of Medicare Part A had envisioned. Instead, grafting separate government insurance programs for seniors, the poor, and the disabled onto the system of voluntary employmentbased insurance for able-bodied working-age Americans only served to dampen calls for comprehensive national health insurance in the United States for the time being. ${ }^{18}$ Subsequent Republican and Democratic administrations considered national health insurance proposals, but these went nowhere. The next major push for national health insurance would come in the late 1980s and early 1990s, with interest groups far more splintered and seemingly incapable of forging a coalition for positive politics action.

\section{HYPERPLURALISM AND THE DEATH OF HEALTH SECURITY IN 1994}

The 1980s saw skyrocketing health care costs, which translated into a 90 percent hike in premiums for employmentbased insurance between 1987 and $1993 .{ }^{19}$ U.S. employers came to view this trend as an unsustainable assault on their profitability and survival. In the brave new world of globalization, manufacturing giants like General Motors faced stiffer competition from overseas competitors enjoying the advantage of much lower labor costs. Even on their home turf, firms offering health insurance had to shoulder higher labor costs, which put them at a competitive disadvantage to rivals who did not. In 1989 Chrysler took the unheard-of step of publicly calling on the government to enact national health insurance..$^{20}$ If all firms were forced to offer insurance to their workforce, it would level the competitive playing field. This new reality, in turn, drove a wedge in the coalition that had long opposed national health insurance, as employers began to resent the profits of health care providers and insurers at their expense. However, the hyperpluralistic interest group universe in U.S. politics made it difficult to assemble a successful coalition able to support a national 
health insurance plan. Instead, interest groups proved themselves far better at blocking reform rather than fostering or sustaining it.

\section{President Clinton and Health Security}

Yet the chances for the passage of national health insurance were encouraging at the start of Democrat Bill Clinton's presidency in 1993. Clinton had made health care reform, along with economic issues, a centerpiece of his presidential campaign, and for good reason. In 1991, Harris Wofford scored an upset victory in a special election for a Senate seat in Pennsylvania by running on a platform promising to enact universal health insurance. More Americans were losing health insurance as they lost their jobs in the recession or as their employers, facing unacceptable premium hikes, dropped coverage. Opinion polls showed that Americans were deeply worried about losing their workplace health insurance, with majorities agreeing that the health care system needed to be "totally rebuilt" and in favor of the federal government guaranteeing universal coverage. ${ }^{21}$

Clinton believed that national health insurance, based in the familiar setting of employment and provided by private insurers, would inoculate himself and his party against charges of socialized medicine and would appeal not only to the uninsured, but also to the middle class facing economic insecurity in the recession and to the business community complaining about rising costs. Representing the "New Democrat" wing of his party, Clinton sought to jettison the party's tax-and-spend, big-government image that had cost it the support of the middle and working classes that had defected to President Ronald Reagan (1981-1989). The New Democrat wing championed public-private initiatives and market solutions to public policy problems, in contrast to some of their older colleagues who had been active in the New Deal and Great Society battles. New Democrats also reckoned that their strategy would help forge a new electoral coalition among the middle class, the working class, and the poor and would overcome traditional wedge issues, such as social welfare, which divided voters on race and class lines. ${ }^{22}$ This calculus was plausible, because Clinton enjoyed Democratic majorities in both houses of Congress, even though he was elected president on a plurality of 43 percent of the popular vote. ${ }^{23}$

\section{Content of Health Security}

Clinton's national health insurance plan, which he dubbed Health Security, reflected this effort to span this wide electoral and interest group divide. It would build on existing employment-based private insurance but would achieve universal coverage by mandating all employers to offer coverage to their workforce. Insurance would be financed primarily by payroll taxes but also excise taxes. Small businesses would receive federal tax credits to make such coverage affordable. Medicare and Medicaid would have survived as separate entities but would have been subjected to cuts in their budgets.

The Clinton plan contained several innovations intended to realize the twin goals of universal access and cost containment in health care. Foremost among these was managed competition, which involved government regulation of the insurance market to ensure universal access to care and competition and choice among health plans to encourage cost containment. The idea for managed competition came from Stanford health economist Alain Enthoven, who first proposed such a scheme in 1980 and refined it in subsequent journal articles. ${ }^{24}$ Managed competition under Health Security would require all employers to offer their workers at least three plans that would differ in terms of cost-sharing, premiums, and choice of providers. The reformers expected that employees would choose the lower cost plans, thus bringing down health care costs. At the same time, managed competition set new restrictions on insurers to bar them from competing by cream-skimming. Instead of enrolling healthy people and excluding the sick from coverage through coverage denials and preexisting conditions exclusions, insurers would now be required to offer a comprehensive basic benefits package to all applicants, charge community-rated premiums that would effectively spread health risks by levying the same rate for all in a region rather than differentiating by a person's medical condition, and have plans with healthier members make risk-adjusted payments to plans with sicker members. Further, insurers would not be able to deny coverage to enrolled members when they became sick by means of invoking preexisting condition exclusions. Responsibility for administration of the health care system would be split between the federal and state governments. State governments would create and administer the individual and small-group insurance markets (or delegate this job to a nonprofit entity). Employers with at least five thousand employees could opt out of the state exchanges and instead assume their own financial risk for insuring their members, which many already did as self-insured plans. At the national level, Congress would set and update the basic benefits package. Finally, a National Insurance Board with members appointed by the president would have the authority to regulate alliances and health plans, and even to limit premium increases to the rate of inflation in the event that competition failed to deliver health care cost containment.

Clinton publicly launched his health care reform plan in a speech to Congress and the American people on September 22, 1993. Opinion polls shortly following the speech showed that most Americans were supportive of Health Security. Yet hopes for passage of Health Security were dashed in the ensuing year. The president's proposal never made it to a floor vote in Congress even though the 
Democratic Party enjoyed majorities in both the House and Senate. By August 1994, health care reform was dead. In the congressional midterm elections, the Democrats lost control of both houses of Congress to the Republicans, a political event not seen since 1952 .

\section{Shutting Out Stakeholders}

This spectacular turn of events was owed to the mobilization of an anti-reform coalition led chiefly by health insurers and employers allied with congressional Republicans. The strategy that President Clinton chose to undertake health care reform had to bear much of the blame for this outcome. It was as though he and his advisers had ignored the realities of U.S. politics, especially separation of powers, party indiscipline, and the extreme pluralism of the interest group universe. The president created a special task force in early 1993 to draw up health care reform, but the way he did so alienated potential allies. Clinton appointed his spouse, Hillary Rodham Clinton, and his close friend and political adviser Ira Magaziner to head the task force. Though Hillary Clinton possessed ample expertise and knowledge in health policy, neither she nor Magaziner were cabinet members subject to Senate confirmation. As a result, they lacked legitimacy that such a confirmation process might have provided. Far worse was that the task force and its affiliated committees of experts worked behind closed doors and shut out Democratic members of Congress with years of experience in health policy. Feeling snubbed by the president, Democratic and Republican members of Congress produced their own competing versions of health care reform so that as many as seven bills were being considered by Congress in 1994. The task force was equally insensitive to the need to win over important health care stakeholders, such as associations representing employers and insurers. While formally consulted in task force hearings, they were not official members of the task force and therefore were denied the opportunity to take part in real negotiations and the resultant give-and-take that would have accompanied such a process. With the growing opposition to Health Security, the Clinton administration also made matters worse by embarking on a public campaign to demonize the insurance industry, which only further riled up the opposition. In short, the exclusionary strategy the Clintons adopted proved to be a recipe for disaster. Notably, it was the polar opposite of President Johnson's strategy of co-optation of key interest groups and congressional leaders that culminated in the successful enactment of Medicare and Medicaid.

\section{Interest Groups and Health Security}

The interest group universe in 1994 was very different from 1965. It was a much more crowded field, with more than eleven hundred groups with a stake in the outcome of health care reform..$^{25}$ The sheer number of groups made it difficult to build a broad coalition in favor of health care reform. Nor were there a few peak associations that could speak authoritatively for their sector. Interest groups were far better at exerting negative power to block policy than to take positive action to enact it. ${ }^{26}$

Nowhere was this more apparent than with the business community, which lacked an overarching peak association to speak authoritatively on its behalf. Instead, businesses had several different organizations representing them, and they were badly divided on health care reform. The Business Roundtable and the U.S. Chamber of Commerce initially supported national health insurance but backed off in the face of revolts from their membership. The Chamber of Commerce also had to stanch the hemorrhaging of members who were defecting to the National Federation of Independent Business (NFIB), a rival association that was vocal in its opposition to the employer mandate..$^{27}$ Business associations thus proved far more adept at representing the interests of their own firm or sector, exerting negative power to block legislation they did not like. ${ }^{28}$

This disarray among large firms and other potential allies of Health Security left the field open to groups firmly set against reform and far better able to mobilize their grassroots members. The two most effective foes to enter the fray were the NFIB and the HIAA, which mobilized their base among smaller insurers who feared for their survival in the world of managed care, and they ran a highly effective series of television ads targeted to sway members of Congress in key districts. In contrast, the forces favoring national health insurance expressed at best lukewarm support for Health Security. Groups such as AARP and organized labor proved no match for the opponents in getting their members involved. Also notable was the phenomenon of "reverse lobbying" by Republican congressional leaders who pressured business associations such as the Chamber of Commerce to take a neutral stance on health care reform or else risk the loss of congressional action on other legislation that business held dear. ${ }^{29}$ The AMA, however, was striking in its lack of influence over the reform debate. Like other interest groups, the president's task force had shut it out of negotiations on Health Security. Moreover, with the loss of members and the growth of rival physician organizations in the years since the passage of Medicare and Medicaid, the association could no longer plausibly claim to be the exclusive voice of the medical profession. Instead, the AMA was just another interest group in the battle over health care reform. ${ }^{30}$

Finally, Health Security contained some key elements that proved to be difficult to sell to the American public. Chief among these were the health alliances. 
Although the president insisted that they were not government entities, the nonpartisan Congressional Budget Office thought otherwise and figured them into its cost estimates for Health Security. Congressional Republicans, meanwhile, seized on the complexity of Health Security and the unfamiliarity of many of its provisions, especially health maintenance organizations (HMOs), and won the battle for public opinion by portraying the legislation as a government leviathan that would stifle patients' choice of doctor and kill off small businesses. With Health Security's allies sitting on the sidelines and belatedly launching an anemic counteroffensive, the field was left to health care stakeholders and Republicans who waged a spectacular campaign of opposition through an onslaught of lobbying and political ads. Opinion polls reflected the effectiveness of this cam-

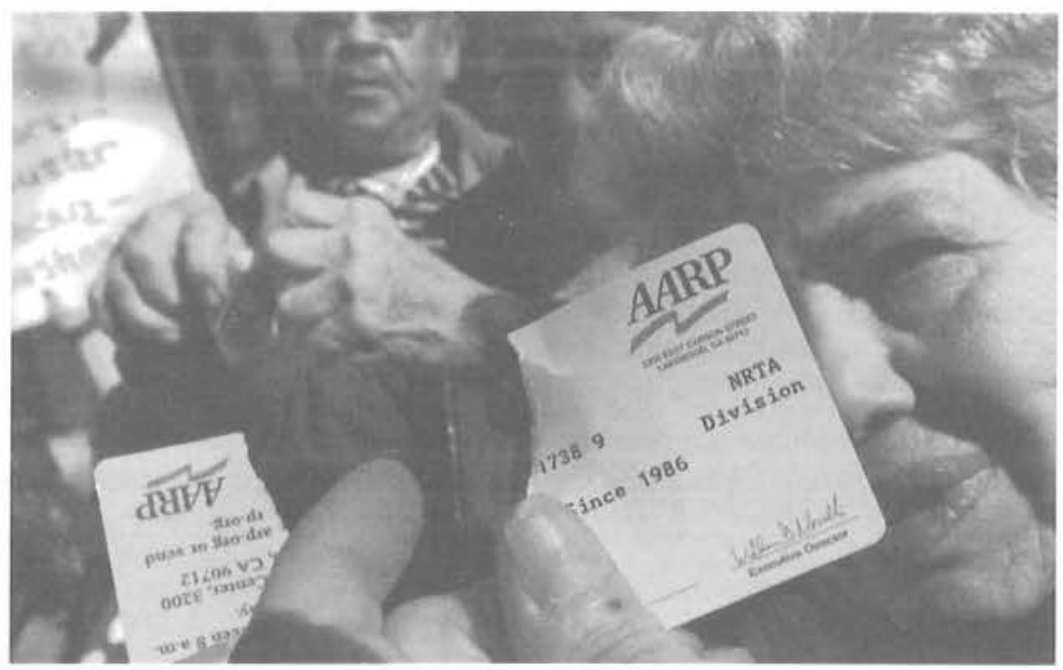

AARP (formerly the American Association of Retired Persons) calls for citizens age fifty and older to make their views known about Medicare and Social Security. With more than thirty-seven million members, AARP is usually a powerful and outspoken lobbying group on issues of concern to older Americans.

SOURCE: Mario Tarna/Getty Images. paign: while 59 percent of poll respondents had expressed support for Health Security right after Clinton's September 1993 speech, that dropped to 46 percent by February 1994 and never recovered, hovering between 42 and 44 percent by summer $1994 .^{31}$

\section{Employers and Health Care Cost-Cutting Strategies}

Following the government immobility on health care reform, employers followed a go-it-alone strategy to control their own health care outlays. In essence, they used competitive forces and managed care but with none of the rules to safeguard the sick that Health Security would have provided. Instead, employers herded their workers into managed care plans that controlled costs by means of preauthorizing (often denying) expensive high-tech procedures and referrals to specialists, putting physicians at financial risk for the health of their patients via capitated payments. Some of the goals and practices of managed care were laudatory, such as coordinating care through primary care doctors and moving away from the perverse more-isbetter incentives of fee-for-service reimbursement. Other practices, however, were less benign and even harmful to patient care. These included financial bonuses to physician reviewers who met a targeted level of treatment denials, paying bonuses to groups of doctors for staying within a preset financial target, and basing medical treatment denials on the absence of agreed-upon clinical practice guidelines based in scientific research. Whereas fee-for-service reimbursement had encouraged physicians to perform more procedures and more expensive ones, the managed care revolution contained equally perverse incentives but in the opposite direction, tempting insurers and providers to reduce access to care even if it was medically necessary. In the absence of good information on clinical effectiveness and of a legal framework to prohibit insurers from engaging in such practices or mandating coverage to all patients, competition became a sledgehammer to pulverize the weakest market players, especially small firms and sicker patients. At the same time, the utilization review processes adopted by insurers spawned a gargantuan private sector bureaucracy of medical reviewers and claims processors.

Managed care without adequate regulation allowed insurers and employers to trim health care costs for a few years in the mid-1990s, but at the expense of inciting a backlash. Managed care horror stories abounded. ${ }^{32}$ Facing rising employee dissatisfaction with their health insurance, employers retreated and offered them health plans with more choices and less management of patients' treatments. With this accommodation, however, the upward trend in health insurance premiums resumed. Between 1999 and 2011, premiums for employer-based health insurance more than doubled. Coverage of an individual employee rose from $\$ 2,196$ to $\$ 5,791$ in those years, while premiums for family coverage jumped from $\$ 5,429$ to $\$ 15,073 .{ }^{33}$ Firms responded by shifting the rising cost of health insurance onto their employees by means of passing on the premium hikes. In addition, high-deductible health plans became more common, especially among smaller firms, as did 


\section{The Fight against Health Security}

The battle over President William J. Clinton's Health Security proposal dramatically illustrated the negative influence of interest groups in the policy process. Along with more traditional techniques of lobbying legislators and mobilizing grassroots members, the episode also witnessed the deployment of novel lobbying techniques, such as politicians reversing the usual direction of influence and leaning heavily on interest groups for their particular stances on health care reform.

The myriad interest groups representing health care stakeholders also made the forging of a unified coalition in favor of reform extremely challenging. Groups representing a specific interest or sector often were at odds with one another. Nowhere was this more apparent than with employers, who lacked a single peak association to speak on their behalf or to coordinate their political strategies. Associations such as the Business Roundtable, which represented large corporations, tended to be supportive of Health Security. However, the small business association, the National Federation of Independent Business (NFIB), was virulently opposed to the Clinton plan and, in particular, its employer mandate. The Chamber of Commerce found itself in the crossfire. The association had endorsed universal coverage and some form of employer mandate to finance it. Yet it took flak for its stance from its own base, which in turn had been goaded to action by congressional Republicans. The Chamber of Commerce also saw defections to its rival, the NFIB. In the face of these pressures, the Chamber reversed its position and officially abandoned its support for universal coverage and an employer mandate.

Insurers were also badly split on health care reform. Larger commercial insurers, which already had HMO plans, anticipated the influx of millions of new customers under the Clinton plan. Small insurers viewed managed competition with trepidation, believing they might not survive, The Health Insurance Association of America (HIAA) was the trade group representing large and small insurers. Its internal divisions prompted larger insurers to exit the HIAA and form its own organization to lobby in favor of Health Security. The HIAA took up the cause of small insurers and launched a series of television ads deriding Health Security. The ads featured a fictional middle-class, middle-aged couple, Harry and Louise, poring over Health Security and opining that the Clinton plan would amount to government intrusion into the patient-doctor relationship, with the government making choices about one's personal health care. The ads were very effective in tapping into Americans' vague but deep-seated fears of big government. Moreover, the HIAA targeted the ads to run in key congressional districts in order to have maximum impact on the most vulnerable legislators.

The once-powerful American Medical Association (AMA) was just another interest group in this crowded health policy field. For one thing, it no longer had the majority of doctors as members and had to contend with rival medical associations. This reality undermined its claim as the sole and legitimate voice of the medical profession. In addition, the coalition of doctors, insurers, and employers that had led successful charges against national health insurance in previous decades by now had splintered, with cost-conscious employers challenging insurers and providers, and insurers, in turn, questioning doctors' unlimited professional freedom in treatment and income decisions. The AMA itself was deeply divided over health care reform and sent a mixed message publicly supporting some aspects of the Clinton plan (such as universal coverage) while stopping short of endorsing it outright. Many members feared the reforms would limit their incomes and clinical freedom. Coming under heavy fire from the NFIB and congressional Republicans, the AMA eventually backtracked on its timid support of health care reform. ${ }^{34}$

The overall effect of this tidal surge of interest groups arrayed against Health Security was telling: erstwhile allies turned into opponents of reform or just retreated to the sidelines. Public support for the Clinton plan tumbled. Congress, in turn, decided to take a pass and let the various reform proposals die in committee. Interest groups may not have been solely responsible for the death of health care reform, but they certainly were "accessories to the crime."

SOURCES: Susan Giaimo, Markets and Medicine: The Politics of Health Care Reform in Britain, Germany, and the United States (Ann Arbor: University of Michigan Press, 2002), 168-176; Cathi Jo Martin, Stuck in Neutral: Business and the Politics of Human Capital Investment Policy (Princeton, NJ: Princeton University Press, 2000), ch. 6; Theda Skocpol, Boomerang: Clinton's Health Security Effort and the Turn against Govemment in U.S. Politics (New York: W.W. Norton, 1996).

health plans with substantial coinsurance and copayments provisions that were shouldered by employees as out-ofpocket expenses. According to Milliman, the total cost of health insurance for a typical family of four, which included not only premium hikes but also the cost-sharing arrangements just described, jumped from $\$ 9,235$ in 2002 to $\$ 19,393$ in $2011 .^{35}$

Nor did managed care or an expanding economy in the 1990 s do much to stanch the rising tide of uninsured, which stood at 40.6 million, or 15.4 percent of the nonelderly population, in 1995 to 47 million, or 17 percent, in 2007, the year before the onset of the Great Recession. ${ }^{36}$

\section{BRINGING STAKEHOLDERS BACK IN: THE PATIENT PROTECTION AND AFFORDABLE CARE ACT OF 2010}

The Great Recession that hit in 2008 ushered in an era of economic insecurity not seen in the United States since the Great Depression of the 1930s. The root cause lay in the reckless lending and trading practices of investment banks in the real estate market. When the housing bubble burst, it brought the rest of the economy to the brink. Unemployment, which had stood at only 4.4 percent in 2007 , rose quickly to peak at 10 percent in October 2009. ${ }^{37}$ To avert a complete 
breakdown of the international financial system and a major economic depression, national governments in the United States and Europe had to intervene with massive taxpayer bailouts of the banks. In the United States, government bailouts also extended to the car industry, which faced steeply falling demand and the near bankruptcy of General Motors and Chrysler. Such government intervention in the economy had not been seen since the Great Depression and World War II (1939-1945).

Naturally, the turbulent economy had major repercussions in health care, because most working-age Americans and their dependents received health insurance from their workplace. Mass unemployment drove up the numbers of uninsured. Each 1 percent increase in unemployment translated into one million Americans losing their health insurance coverage. The U.S. Census Bureau estimated that 49.2 million people, or nearly 20 percent of Americans under age sixty-five, were uninsured at the peak of the recession in $2009 .^{38}$ Yet government programs like Medicaid and the Children's Health Insurance Program for the poor and nearpoor were unable to cover all of these uninsured people. ${ }^{39}$ The state and federal governments fund these programs jointly, but the states were facing huge budget gaps owing to the recession-induced fall in tax revenues plus greater demand for such health care programs and unemployment benefits. Furthermore, state governments did not have much maneuvering room; unlike the federal government, nearly all state constitutions require their governments to balance their budgets annually. This foreclosed the option of deficit spending. Other than in states such as California, most governors did not want to raise taxes to pay for additional state outlays. Lastly, the Medicaid and Children's Health Insurance Program coverage rules excluded certain people by design: they covered poor families with children but left out low-income childless adults. The health care safety net was stretched so tightly that it was fraying in many places.

\section{Barack Obama and Health Care Reform}

The political terrain had also shifted, with Democrats recapturing the White House after eight years of Republican rule. Democratic President Barack Obama soundly beat his Republican rival Senator John McCain in the November 2008 election, and Democrats also secured comfortable majorities in both houses of Congress. Obama had placed health care reform at the front and center of his campaign, and the election results indicated that he had a mandate for action. Even so, the economic crisis at first glance seemed an inauspicious environment in which to undertake any major health care reform. Paradoxically, however, the desperate economy provided an opening for a health care overhaul. The federal government had already intervened in the economy with its bailout of the banks and the car industry.
If the banks, which were responsible for the mess, could receive billions of dollars of government aid, should not the millions of ordinary Americans experiencing unemployment and loss of their health insurance obtain a helping hand from the government? With this argument, Obama and his advisers turned vice into virtue and transformed the economic crisis into a window of opportunity to move forward the plan for health care for all.

What sort of health care reform would Obama and the Democrats enact? How would it expand access to the growing millions of uninsured? Also, how could it avert potential opposition from key health care interest groups who had wrecked past efforts at reform? The left wing of the Democratic Party and labor union allies wanted a singlepayer tax-financed government insurance plan, or "Medicare for all," along the lines of Canada's plan, but the fiscally conservative "Blue Dog" wing of the party could not countenance such an expansion of government outlays. Others seeking a third way between these two wings proposed a government health plan to compete alongside private employment-based insurance. This "public option," or "Medicare for some," would have stopped well short of a universal government plan and accordingly would have put less strain on the federal budget. Yet like the Medicare program, it would have enjoyed the economies of scale and the market power to negotiate lower reimbursement rates with providers and hopefully would force private insurers to do the same in order to stay competitive. ${ }^{40}$ The public option naturally offended insurers, who foresaw smaller profits as a result, as well as providers like the AMA and AHA, who feared lower reimbursements. Liberal Democrats hoped that the public option would be the first step toward a single-payer insurance plan for all Americans, while conservatives feared the same fate. In the end, the plan did not have enough votes to pass the Senate, and President Obama declared his willingness to jettison the proposal in order to ensure passage of health care reform in that chamber.

\section{The Need for Compromise}

The compromise solution that Democrats finally agreed on retained employment-based private insurance for most Americans (since they already had it) while making it more affordable to them via income-based tax credits. In addition, Medicaid would be expanded to cover all individuals, even adults without children, but with incomes at or below 138 percent of the federal poverty limit. An online marketplace, or exchange, for health insurance for individuals and small businesses would operate in each state. The exchanges would put into practice the theory of managed competition: insurers in the exchanges would compete on price of premium and associated cost-sharing, but not on health risks. A transparent easy-to-compare format, much like the site Travelocity for airfares, would make it easy for consumers to 
shop for the plan that fit their needs. All insurers, whether inside or outside the exchanges, would no longer be able to exclude the sick from coverage through preexisting conditions clauses or experience-rated premiums. Instead, they would have to accept all applicants, would not be able to drop coverage based on health status, and would have to charge community-rated premiums that would vary only by sex, family size, region, and whether a person smoked. In addition, insurers in the exchanges that had a disproportionate share of sicker members would receive risk-adjusted payments from those that did not.

Many of the features of the Patient Protection and Affordable Care Act, then, looked very similar to President Clinton's Health Security plan of nearly two decades earlier. Instead of alliances there were now exchanges, competition coupled with consumer safeguards would control costs, and employment-based insurance would remain the norm for most Americans. There were also important differences. Unlike the Clinton plan, the PPACA went beyond reform of the insurance market to address, albeit tentatively, the inflationary features inherent in the organization and delivery of health care. Thus, the government encouraged but did not mandate experiments with bundled payments to providers (flat-rate payments per case or per episode of care) paired with financial rewards for improved patient health outcomes, encouraged new forms of medical practice such as accountable care organizations and patient-centered medical homes to coordinate the care of patients with chronic diseases, and provided funding for providers to adopt electronic medical records to make such coordinated care and measurement of health outcomes a reality.

The major departure from the Clinton plan concerned the question of financing health insurance. Instead of mandating all employers to offer insurance as the Clinton plan had proposed, the PPACA imposed the insurance mandate on individuals. However, it would come with tax credits up to 400 percent of the federal poverty limit so that insurance would be affordable for those in the lower and middle classes. The PPACA stopped short of an employer mandate, but it gave firms incentives to do so under a "play-or-pay" scheme: employers who refused to provide insurance would pay a financial penalty for each of their full-time workers. This fine would be used to pay for their employees seeking insurance in the individual market. However, small businesses would be exempt from play-or-pay.

Interestingly, the idea of an individual mandate had long been proposed by political conservatives. They had proposed the individual mandate as a way to decouple health insurance from employment. The individual mandate would place responsibility for health insurance on individuals but would also give them the freedom to shop around for a health plan that met their needs rather than have their employer choose one for them. In the 2008 presidential election campaign, the individual mandate was the centerpiece of John McCain's health care reform proposal. Candidate Obama himself was initially skeptical of the need for such a mandate and believed that subsidies for lower income people would be sufficient to convince them to sign up for insurance voluntarily. However, his advisers subsequently convinced him that the mandate was critical to the survival of insurance markets because it would allow for the pooling of the healthier with the sicker.

The PPACA not only based itself on the theoretical model of managed care laid out in the Clinton health plan, but it also drew on the real-world example of the Massachusetts Health Plan. Enacted by a Democratic-controlled legislature and Republican governor Mitt Romney (in office 20032007), who signed it into law in 2006, ${ }^{41}$ the Massachusetts Health Plan introduced near-universal coverage of state residents through private employment-based insurers. It outlawed insurers' practices that discriminated against the sick. It created an online exchange where small businesses and individuals in the state could shop around for coverage from competing private insurers. Finally, an individual mandate and the play-or-pay provisions for employers were also features, as were tax credits for those on low incomes to make insurance affordable.

\section{Cutting Deals with Health Care Stakeholders}

If the PPACA borrowed much from the ill-fated Clinton plan, why did Congress enact it? Also, why did health care stakeholders not set out to destroy it as they had Health Security nearly two decades earlier? The answer lies in the very different strategy that President Obama and congressional Democrats pursued, which was quite the opposite of the one that the Clintons had followed. Obama and Democratic leaders in Congress took into account the dangers presented by powerful health care interest groups and the fragmented political system's capacity to destroy party unity and to provide numerous veto points to organized interests, and they plotted their strategy accordingly. That strategy entailed maintaining intraparty unity and bringing key interest groups early on into real negotiations in order to gain their support of reform. Obama showed a willingness to make strategic concessions with both congressional Democrats and health care interest groups in order to keep reform on track. At the same time, allies of the PPACA were far more effective in mobilizing grassroots support and maintaining unity than in 1994.

Democratic leaders decided to unify the different committee bills into a single piece of legislation for consideration in each chamber. Such action focused Democratic minds on one bill rather than on several competing versions of reform that had exerted such a centrifugal effect on party unity during 1993 and 1994. In a further departure from the Clinton strategy, Obama also decided to give Congress the 
lead in drafting health care reform legislation. This deference did much to forge a partisan bond able to traverse the institutional chasm created by separation of powers.

The most important concession that Obama made to ensure party unity was to drop the public option from the final version of health care reform. This was done as the politics of necessity, in large part to ensure Democratic Party unity across the different branches of government. House Democrats, who enjoyed a comfortable majority and whose Speaker was among the liberal wing of the party, had the votes (just barely, as it turned out) to include a watereddown version of the public option in their reform bill. The situation in the Senate was quite different. In that chamber, the moderate wing of the Democratic Party was stronger and the party's majority of seats was less assured under the filibuster, which allowed a minority of forty-one senators to block a floor vote on a bill. Were the public option included in the Senate reform bill, the defection of even a few moderate Democratic senators would have been enough to kill the legislation in a Republican-led filibuster. Aware of the numbers in the Senate, Obama announced his willingness to drop the public option from the final reform bill. Accordingly, the bill that made it out of the Senate did not have this feature, and House Democrats grumblingly reconciled themselves to this reality.

Aside from compromising and including congressional Democrats in the project of health care reform, the other striking difference was the approach of the Obama administration and traditional advocates of national health insurance toward groups normally opposed to reform. Instead of trying to freeze out health care stakeholders as the Clintons had done, the president brought key interest groups to the negotiating table early on. The hope was to forge a consensus on the content of reform that could withstand the onslaught from opponents of reform that was certain to follow during the long and tortuous legislative process. The strategy of stakeholder inclusion consisted of two parts. The first was bringing interest groups to the table as genuine negotiating partners. The second was the mobilization of a powerful and unified interest group coalition that brought together previous foes who were now determined to see reform through.

The effort to win over powerful interests that had blocked past efforts at national health insurance was not just the administration's purview. Rather, Obama relied on key politicians and interest group leaders as well. Senator Edward "Ted" Kennedy (D-MA; in office 1962-2009), a longtime advocate of universal health coverage who was suffering from terminal brain cancer, held closed-door talks with major health care stakeholders, many of whom had bitterly opposed the Clinton plan, to see if he could build a consensus on a new health care reform effort that would expand access to insurance and control costs. Health insurers and providers were attracted to gaining new markets among the uninsured, while employers wanted a solution to their skyrocketing labor costs. ${ }^{42}$ In May 2009, Obama announced the outlines of a breakthrough with major health care stakeholders. In a letter addressed to the president, the interest groups pledged to work together to slow the rate of health care inflation by 1.5 percent in the decade from 2010 through 2019. The list of participants at the announcement was a who's-who of the medical industrial complex: the AMA; the AHA; the Pharmaceutical Research and Manufacturers of America (PhRMA); the Advanced Medical Technology Association, which represented medical device manufacturers; America's Health Insurance Plans (AHIP) representing health insurance companies large and small; and the Service Employees' International Union (SEIU). Published in The New York Times on May 11, 2009, the letter noted, in part:

We are committed to taking action in public-private partnership to create a more stable and sustainable health care system that will achieve billions in savings through:

Implementing proposals in all sectors of the health care system, focusing on administrative simplification, standardization, and transparency that supports effective markets;

Reducing over-use and under-use of health care by aligning quality and efficiency incentives among providers across the continuum of care so that physicians, hospitals, and other health care providers are encouraged and enabled to work together towards the highest standards of quality and efficiency;

Encouraging coordinated care, both in the public and private sectors, and adherence to evidence-based best practices and therapies that reduce hospitalization, manage chronic disease more efficiently and effectively, and implement proven clinical prevention strategies; and,

Reducing the cost of doing business by addressing cost drivers in each sector and through common sense improvements in care delivery models, health information technology, workforce deployment and development, and regulatory reforms.

None of the groups specified what exactly they would do to reach this ambitious goal but instead pledged to work with the president and each other to get there. All realized, however, that they would have to accept some responsibility for financing the expansion of coverage to the uninsured. It was in their self-interest to do so, as fewer uninsured translated into more certain incomes for providers and new markets for insurers. ${ }^{43}$

Interestingly, the person instrumental in bringing representatives of the health care industry to the agreement in May 2009 was not one of their own but Dennis Rivera, who led the health care reform campaign of the powerful SEIU 
and saw affordable employment-based insurance as vital to preserving union jobs. Thus, Rivera got employers (including Wal-Mart), health care providers, and insurers on board with health care reform. The SEIU's president, Andy Stern (himself a maverick reformist labor leader on the left wing of the labor movement, who had taken his union out of the AFL-CIO in 2005 over differences in organized labor's strategy), justified his union's strategy to forge an alliance on health care reform with traditional labor foes:

If the business community, the pharmaceutical industry and Wal-Mart all opposed health care reform, this bill would be dead. ... What keeps it alive is that conservatives are isolated from their traditional business base. The business community appreciates that our country needs to do something about health care. ${ }^{44}$

The Obama administration and its Democratic allies in Congress offered key concessions to providers, insurers, and employers in order to prevent a repetition of their obstruction that had been so damaging to the fate of Health Security in 1994. One by one, their associations cut deals with the administration. In some cases, the deals were sweet, in other cases, they were not. The pharmaceutical industry was the first to move. PhRMA agreed to close the gap in Medicare Part D drug coverage insurance (the so-called donut hole) by granting discounts of 50 percent for namebrand drugs and promising to spend $\$ 150$ million in ads supportive of health care reform. In return, Obama agreed to keep many of the Medicare Part D provisions that would maintain the hefty profit margins of the industry. Under the PPACA, the Medicare program would not be able to negotiate drug prices with manufacturers or reimport cheaper prescription medicines from abroad.

Like the pharmaceutical industry, other provider groups made concessions in exchange for new revenues that an expansion of coverage to the millions of uninsured would bring them. The AMA publicly came out in favor of the House version of reform on the eve of that chamber's vote. The association was relieved at Obama's subsequent decision to drop the public option. Many of the AMA's members were well acquainted with the lower Medicare reimbursements compared with those of private insurers and feared that a public option would do the same for their treatment of working-age Americans. Hospitals, too, were satisfied with the elimination of the public option for similar reasons as physicians. To be sure, the AHA had to give some ground. Hospitals agreed to cuts in government reimbursements of $\$ 155$ billion over ten years in order to finance the expansion of coverage to the uninsured. Fewer uninsured meant fewer cases of uncompensated charity care for the hospitals to bear. However, the AHA successfully negotiated a ten-year exemption from the introduction of such cuts.

\section{Rejecting the Public Option}

Obama's decision to jettison the public option was crucial to neutralizing the health insurance lobby, represented by AHIP, a merger of AAHP and HIAA. Private insurers feared and loathed the public option because it posed a real threat to their profit margins and perhaps their survival. Indeed, AHIP complained that the public option would enjoy unfair advantages in the marketplace and would essentially drive it out of business. Obama's decision to drop the public option, however, came with a price: insurers had to accept the prohibition of their medical underwriting practices that had allowed them to shun less healthy individuals and small businesses that employed them. At the same time, Obama and the insurance industry found common ground on the need for the individual mandate. Insurance reform entailed that insurance companies would have to accept all applicants and set modified community-rated premiums in place of those based on an applicant's health risk. Yet placing new requirements on insurance companies without also requiring everyone to buy insurance would likely lead to adverse selection, a problem long recognized by many health economists. That is, sicker individuals who had been denied coverage or priced out of the health insurance market would now rush to sign up for insurance. Without healthier people enrolling and offsetting these bad risks, the profits and even survival of insurers might be threatened. By requiring everybody to carry health insurance, the individual mandate would ensure the risk pooling necessary to the proper functioning of insurance markets. The provision for risk-adjusted payments among insurers was also expected to correct for any subtle forms of cream-skimming that insurance companies might try.

Despite these concessions, the insurance industry was unhappy with the direction of negotiations with congressional Democrats and the administration. AHIP argued that its members had already agreed to cuts in reimbursement for the private Medicare plans they offered to seniors. While AHIP recognized the new business that covering thirty million uninsured would bring in, it disagreed with the Democrats' estimates and maintained that it would impose hardship on insurers. However, it proved difficult for the insurance industry to plead hardship under the provisions of the PPACA. After all, the industry had enjoyed ample profits for a number of years. When AHIP tried to mount a campaign to sabotage the passage of the bill, its efforts seemed disingenuous and self-serving. An AHIP-commissioned analysis of the PPACA by the accounting firm PricewaterhouseCoopers found that the law would lead to much higher premiums than the government had indicated. However, the accounting firm later distanced itself from the report and news media exposed its flawed data. Nor did it help that Anthem announced a premium hike of 30 percent for the small-group market. The insurance industry's position was increasingly untenable. 


\section{Concessions to Employers}

The Obama administration also made a number of key concessions to employers that muted their opposition to reform. Chief among these was the requirement that responsibility for insurance rest with individuals rather than employers. The decision to forgo an employer mandate assuaged the fears of many firms over their labor costs. So, too, did the exemption of small firms from the play-or-pay provisions of the law as well as the reward of tax credits to small businesses that opted to provide insurance anyway. These provisions satisfied most large employers. To be sure, the NIFB and U.S. Chamber of Commerce were vocal in their opposition to the PPACA and ran negative ads on the law. However, Obama's accommodations to employers' concerns made business opposition to reform less convincing, and, in fact, many large employers (and even some small ones) supported the PPACA. ${ }^{45}$

The second prong in the reform strategy was engaging grassroots supporters of reform in coordinated action. This was in effect a continuation of the mobilization of the electorate that had swept Obama into office in 2008; the leading groups in this issue-based campaign centering on health care reform were Health Care for America Now (HCAN), Organizing for America (OFA), and MoveOn. These groups coordinated their work and that of other groups favoring reform, such as groups representing segments of the medical profession as well as nurses and other allied health professions, labor unions, and consumer groups. HCAN and OFA organized rallies, circulated Internet petitions, and garnered online contributions to finance this issue campaign. These tactics sustained ordinary citizens' support for health care reform and targeted congressional Democrats in vulnerable districts whose votes for the PPACA were not assured. For example, in 2009, volunteers at a phone bank in Wisconsin called registered Democratic voters living in Ohio whose representative was wavering on reform and whose reelection was not assured. The phone bank volunteer would explain the PPACA to that member's constituents and urge them to vote for their incumbent representative in the upcoming election. This type of mobilization was designed to keep Democratic politicians honest and minimize their defections from the PPACA.

The mobilization of grassroots supporters succeeded on a number of levels. First, proponents of reform would not let differences of opinion destroy health care reform efforts as they had in the past. Though some groups such MoveOn and the AFL-CIO initially pushed hard for the public option, when President Obama made it clear that he would not sacrifice the entire reform project for the preservation of this one idea, they acquiesced. Moreover, they continued to rally their members to support reform and to pressure congressional Democrats to do the same. Their efforts paid off, with Congress just barely enacting the Patient Protection and Affordable Care Act in March 2010.

\section{Impact of the Tea Party Movement}

The pro-reform coalition faced a formidable array of groups that mobilized to kill the bill, but not primarily from the insurance or provider groups. Instead, the main challenge came from the Tea Party movement. The Tea Party movement was not an organized interest group as such, nor was it a political party. Rather, it was a conservative backlash that developed among citizens and erstwhile Republicans in reaction to that party's fiscal profligacy and bank bailouts under President George W. Bush (2001-2009). It consisted largely of higher income white Americans. They generally abhorred big government and especially the Democrats' health care reform plans. While many Tea Party adherents formed spontaneously among grassroots citizens, the movement was also supported financially and otherwise by powerful conservative elites, such as former Republican representative Dick Armey's Freedom Works and the conservative industrialist Koch brothers. ${ }^{46}$ Tea Partiers engaged in a number of actions to try to stop health care reform. In summer 2009, they disrupted town hall meetings, which Democrats had organized to explain and build public support for Obama's reform plans.

Tea Partiers were very effective in shouting down speakers and garnering widespread media coverage in the process. In addition to such direct action, the Tea Party movement sought to reorient the Republican Party by running conservative candidates in Republican primaries for Congress and the presidency. Rather than form a breakaway third party, the Tea Party movement intended to infiltrate the Republican Party in order to steer it back to its true small-government roots. Though failing to block the passage of the Patient Protection and Affordable Care Act, Tea Party candidates did well enough to help the Republicans regain control of the House of Representatives in the 2010 midterm elections; however, they fell short of their aim to retake the White House or the Senate in the 2012 elections.

\section{Critics of the Administration's Strategy}

Critics of the strategy of securing interest group buy-in charged that it was little more than Democrats selling out their principles and buying off their foes. Clearly, health care providers, insurers, and employers look set to do well under the new law. Defenders of this approach, however, argued that it was simply a matter of political necessity, that it was far better for the Democrats to transform traditional foes of health care reform into allies by means of inclusion and cooptation. However, such a strategy required compromise, by many pro-reform leaders and their supporters. 
It also remains to be seen whether the deals struck with health care stakeholders during the enactment of the PPACA will hold. Having failed to gain Republican majorities that could repeal the law outright, the Tea Party's strategy has been to pressure congressional Republicans to block the health care reform law either by delaying its implementation or by defunding the law's key provisions. The Tea Party precipitated a partial federal government shutdown in October 2013 with its insistence on delaying implementation of the PPACA. Providers and insurers may seek to renegotiate or renege on earlier agreements they struck with the Obama administration. Medical device manufacturers pressured House Republicans to include a repeal of the tax on their equipment in their ultimatum on the shutdown in fall 2013, though the measure did not make it through the Democraticcontrolled Senate. Wishing to preempt an electoral backlash in the 2014 congressional elections, the Obama administration decided to delay by one year the introduction of the play-or-pay provisions for large employers.

\section{HEALTH CARE POLICY: GOING FORWARD}

Health care policy in the United States amply illustrates the hyperpluralism of the interest group universe, which has become more crowded with the ascendancy of interest group campaign donations and lobbying in U.S. politics. It is also the result of the unplanned development of employment-based private insurance and the tacking on of public insurance programs for the poor and elderly later on. The result is a health policy arena full of narrow interests with a stake in preserving the status quo. A radical policy shift in this environment is extremely unlikely. ${ }^{47}$ Instead, health care reformers have had to build on the existing edifice of private and public insurance, even if those twin pillars are showing the limits of their ability to uphold the system.

The sheer number of competing groups, even within a specific sector of the economy, poses enormous difficulty for policymakers seeking to forge a compromise agreement. Such agreements, while rare, do happen. They depend on

KEY DECISIONS: HEALTH CARE CRISES AND SOLUTIONS

\section{The Repeal of the Medicare Catastrophic Coverage Act}

In 1989, Congress enacted the Medicare Catastrophic Coverage Act (MCCA). The law would have extended Medicare coverage of hospital and doctor bills above a certain threshold. To pay for these new benefits, wealthier seniors would have faced higher premiums. AARP initially supported the bill but reversed its position after encountering a backlash from its own members. The ensuing opposition from both AARP and the National Committee to Preserve Social Security and Medicare led Congress to repeal the law the following year. Representative Donald L. Ritter (R-PA) introduced the bill to repeal the MCCA on January 3, 1989:

Mr. RITTER. Mr. Speaker, since its passage, I haven't heard one of the 72 Members who voted against the Medicare Catastrophic Coverage Act express regret over their vote, but I've heard complaints from many of those who are sorry they voted for it.

Lately, we've been reading more financial reports advising senior citizens on how to adjust their incomes in 1989 to reduce their tax liabilities. They are coming up with clever strategies to avoid paying the new surtax on their income tax that was imposed on them to pay for a Catastrophic Coverage Act they didn't want. But, this is one New Year's gift from Congress which taxpaying seniors find unwelcome.

In reducing tax liabilities to avoid the surtax, taxpaying seniors will withdraw moneys available for benefits. I'd like to ask my colleagues if they know that the Catastrophic Coverage Act contains a provision requiring that "The Secretary would increase the flat premium to replace revenue" in the case of a revenue shortfall. I fear this might result in not only higher Medicare part B payments, but also higher deductibles, lower levels of service and fewer people covered.

The funding mechanism is self-defeating. ... At a time when society is craving greater savings and investment by seniors to cover retirement expenses, the Medicare Catastrophic Act is a mistake. It's a raw deal for seniors who have saved and invested wisely for their later years. Not only will they have to pay income taxes, but also new surcharges on those taxes for a bill that doesn't even encompass long-term care.

My constituents are writing and calling my office to protest the surtax and the sharp increases in Medicare part B. I understand that's happening in other congressional districts, too. The financing mechanisms in the bill are onerous for our tax-paying senior citizens, given the inevitable reduction of taxable income and assets, they sow the seeds of their own failure. For these reasons, I am introducing a bill to repeal the Medicare Catastrophic Act of 1988 and to establish a bipartisan advisory group to study and develop proposals to provide protection against excessive costs of catastrophic illness beyond the scope of current Medicare coverage.

SOURCE: Introduction of the Bill to Repeal the Medicare Catastrophic Coverage Act of 1989-Hon. Don Ritter (Extension of Remarks-january 03, 1989), Congressional Record, 101st Congress (1989-1990), http//thomas.loc.gov/cgi-bin/query/D?r101:101:/temp/ r101uZ6aBC. 
political and interest group leaders willing to engage in meaningful bargaining with each other and able to bring their base along. When reform does occur, it is invariably drawn out and ugly. Yet such is the pattern of interest group politics in the United States today.

See also Chapter 6: The Centers for Medicare and Medicaid Services (1965-Present); Chapter 19: Children's Health and Health Care Policy (1960sPresent); Chapter 20: Women's Issues and American
Health Care Policy (1960s-Present); Chapter 21: Minorities, Immigrants, and Health Care Policy: Disparities and Solutions (1960s-Present); Chapter 22: Aging and Health Care Policy (1990s-Present); Chapter 23: Fifty Years of Progress in Disease and Injury Prevention (1950s-Present); Chapter 24: Mental Health and Social Policy (1960s-Present); Chapter 25: Nutrition, Physical Activity, and the Obesity Epidemic: Issues, Policies, and Solutions (1960s-Present).

\section{NOTES}

1. Theodore R. Marmor, The Politics of Medicare, 2nd ed. (New York: Aldine de Gruyter, 2000).

2. Theda Skocpol, Boomerang: Clinton's Health Security Effort and the Turn against Government in U.S. Politics (New York: W.W. Norton, 1996); Cathi Jo Martin, Stuck in Neutral: Business and the Politics of Human Capital Investment Policy (Princeton, NJ: Princeton University Press, 2000); Susan Giaimo, Markets and Medicine: The Politics of Health Care Reform in Britain, Germany, and the United States (Ann Arbor: University of Michigan Press, 2002).

3. Premium support for Medicare was first proposed by Henry J. Aaron and Robert D. Reischauer, "The Medicare Reform Debate: What Is the Next Step?" Health Affairs 14: 4 (1995): $8-30$. For the Heritage Foundation's proposals, see Heritage Foundation, Saving the American Dream: The Heritage Plan to Fix the Debt, Cut Spending, and Restore Prosperity (Washington, DC: Heritage Foundation, 2011). The Heritage Foundation's economic analysis of Representative Ryan's budget proposals was done by the Center for Data Analysis, "Economic Analysis of the House Budget Resolution by the Center for Data Analysis at the Heritage Foundation," April 5, 2011. For Ryan's proposals on Medicare, see Paul Ryan, Description of the Legislation: A Roadmap for America's Future, January 27, 2010, 50-52. http://www.americanroadmap.org; Paul Ryan, The Path to Prosperity, House Budget Committee, March 2012, http:// budget.house.gov/prosperity; Alice Rivlin and Paul Ryan, "A Long-Term Plan for Medicare and Medicaid," November 17, 2010, http://budget.house.gov/news/documentsingle.aspx? DocumentID $=225826$; and Ron Wyden and Paul Ryan, Guaranteed Choices to Strengthen Medicare and Health Security for All, December 15, 2011, http://budget.house.gov/uploaded files/wydenryan.pdf.

4. Allan J. Cigler and Burdett A. Loomis, Interest Group Politics (Washington DC: CQ Press, 2002); Leon D. Epstein, Political Parties in the American Mold (Madison: University of Wisconsin Press, 1986); William G. Weissert and Carol S. Weissert, Governing Health: The Politics of Health Policy, 4th ed. (Baltimore: Johns Hopkins University Press, 2012), 174.

5. Weissert and Weissert, Governing Health, 177-179.

6. Ibid., 160-161, 170-171.

7. Ibid., 135.

8. Kay Lehman Schlozman and John T. Tierney, Organized Interests and American Democracy (New York: Harper and Row, 1986).
9. Cigler and Loomis, Interest Group Politics; David Vogel, "Why Businessmen Distrust Their State: The Political Consciousness of American Corporate Executives," British Journal of Political Science 8 (January 1978): 45-78.

10. Marmor, The Politics of Medicare, 18.

11. Weissert and Weissert, Governing Health, 130.

12. Ibid., 132.

13. Ibid., 135 .

14. Donald L. Madison, "From Bismarck to Medicare-A Brief History of Medical Care Payment in America," in The Social Medicine Reader, Vol. III: Health Policy, Markets, and Medicine, 2nd ed., edited by Jonathan Oberlander, 31-66 (Durham, NC: Duke University Press, 2005); Jacob S. Hacker, The Divided Welfare State: The Battle over Public and Private Social Benefits in the United States (Cambridge, UK: Cambridge University Press, 2002).

15. Marmor, The Politics of Medicare, 18; Jill Quadagno, One Nation, Uninsured: Why the U.S. Has No National Health Insurance (Oxford, UK: Oxford University Press, 2005), 64.

16. Marmor, The Politics of Medicare, chs. 1-5; Quadagno, One Nation, Uninsured, 55-76.

17. Quadagno, One Nation, Uninsured, 73-74; Marmor, The Politics of Medicare, 47-55,

18. Marmor, The Politics of Medicare, 56-61.

19. Philip F. Cooper and Barbara Steinberg Schone, "More Offers, Fewer Takers for Employment-Based Health Insurance: 1987 and 1996," Health Affairs 16: 6 (1997): 142.

20. Milt Freudenheim. "A Health Care Taboo Is Broken," New York Times, May 8, 1989.

21. Jacob S. Hacker, The Road to Nowhere: The Genesis of President Clinton's Plan for Health Security (Princeton, NJ: Princeton University Press, 1997), 17-20; Skocpol, Boomerang, 13, 21-23.

22. Hacker, The Road to Nowhere, 16-17.

23. In the 1992 presidential race, incumbent Republican President George H.W. Bush faced a challenge from Democrat Bill Clinton and independent candidate H. Ross Perot. Perot's candidacy drew away support from Bush, allowing Clinton to win with a 43 percent plurality of the popular vote.

24. Alain C. Enthoven, Health Plan: The Only Practical Solution to the Soaring Cost of Medical Care (Boston: Addison-Wesley, 1980); Alain C. Enthoven, "Managed Competition: An Agenda for Action," Health Affairs 7:3 (1988): 25-47.

25. Weissert and Weissert, Governing Health, 132.

26. See Vogel, "Why Businessmen Distrust Their State," for his formulation on the negative power of business groups in U.S. policy. 27. Martin, Stuck in Neutral; Giaimo, Markets and Medicine, ch. 6. 
28. Vogel, "Why Businessmen Distrust Their State."

29. Skocpol, Boomerang.

30. Mark A. Peterson, "From Trust to Political Power: Interest Groups, Public Choice, and Health Care," Journal of Health Politics, Policy and Law 26: 5 (2001): 1145-1163.

31. Skocpol, Boomerang, 75.

32. Robert J. Blendon et al., "Understanding the Managed Care Backlash," Health Affairs 17: 4 (1998): 80-94.

33. Kaiser Family Foundation and Health Research and Educational Trust, Employer Health Benefits, 2011 Annual Survey, http:// kaiserfamilyfoundation.files.wordpress.com/2013/04/8225 .pdf.

34. Giaimo, Markets and Medicine, 175; Skocpol, Boomerang, 161-162.

35. Milliman Medical Index, May 2011, http://www.milliman .com/mmi.

36. Robert L. Bennefield, "Health Insurance Coverage: 1995," U.S. Census Bureau Current Population Reports, P60-195 September 1996, p. 1; Kaiser Family Foundation, Key Facts about the Uninsured Population, September 2013, http://kff.org/unin sured/fact-sheet/key-facts-about-the-uninsured-population.

37. Bureau of Labor Statistics, "Labor Force Statistics from the Current Population Survey," http://data.bls.gov/timeseries/ LNS14000000.

38. Kaiser Family Foundation 2013, p. 3.

39. The Children's Health Insurance Program is the current name of the Medicaid expansion program for children of the working poor. It was originally enacted in 1997 as the State Children's Health Insurance Program.

40. Jacob S. Hacker, "Putting Politics First," Health Affairs 27: 3 (2008): 718-723; Jacob S. Hacker, The Case for Public Plan Choice in National Health Reform: Key to Cost Control and Quality Coverage (Berkeley: Center on Health, Economic and Family Security, University of California School of Law, and Institute for America's Future, 2008), https://www.law .berkeley.edu/files/Jacob_Hacker_Public_Plan_Choice.pdf.

41. On the Massachusetts Health plan, see Kaiser Family Foundation, Massachusetts Health Care Reform: Six Years
Later, May 2012, http://kff.org/health-costs/issue-brief/massa chusetts-health-care-reform-six-years-later.

42. Stuart Altman and David Shactman, Power, Politics, and Universal Health Care: The Inside Story of a Century-long Battle (Amherst, NY: Prometheus Books, 2011), ch. 12, esp. 254-255.

43. Steven Greenhouse, "Dennis Rivera Leads Labor Charge for Health Reform," New York Times, August 27, 2009; Robert Pear, "Industry Pledges to Control Health Care Costs," New York Times, May 11, 2009.

44. Greenhouse, 2009.

45. Altman and Shactman, Power, Politics, and Universal Health Care, ch. 12.

46. Edward Luce and Alexandra Ulmer, "Obama Foes Turn to '60s Radical for Tactical Tips," Financial Times, August 17, 2009, 2; Kate Zernike and Megan Thee-Brenan, "Poll Finds Tea Party Backers Wealthier and More Educated," New York Times, April $14,2010$.

47. Hacker, The Divided Welfare State,

\section{FURTHER READING}

Altman, Stuart, and David Shactman. Power, Politics, and Universal Health Care: The Inside Story of a Century-long Battle. Amherst, NY: Prometheus Books, 2011.

Jacobs, Lawrence R., and Theda Skocpol. Health Care Reform and American Politics: What Everyone Needs to Know. Rev. ed. Oxford, UK: Oxford University Press, 2012.

Marmor, Theodore R. The Politics of Medicare. 2nd ed. New York: Aldine de Gruyter, 2000.

Quadagno, Jill. One Nation, Uninsured: Why the U.S. Has No National Health Insurance, Oxford, UK: Oxford University Press, 2005.

Skocpol, Theda. Boomerang: Clinton's Health Security Effort and the Turn against Government in U.S. Politics. New York: W.W. Norton, 1996.

Weissert, William G., and Carol S. Weissert. Governing Health: The Politics of Health Policy. 4th ed. Baltimore: Johns Hopkins University Press, 2012. 